\title{
Medical Staff Attrition in Local Authorities: Experiences from Harare City Council Maternity Clinics (2007-2008)
}

\author{
Alois Madhekeni (Corresponding author) \\ Department of Political and Administrative Studies, Faculty of Social Studies \\ University of Zimbabwe, P.O. Box MT Pleasant Harare Zimbabwe \\ Phone: +263772 $754831 \quad$ E-mail: madhekeni@yahoo.com
}

Hope Taderera

Department of Political and Administrative Studies, Faculty of Social Studies

University of Zimbabwe, P.O. Box MP 167 MT Pleasant Harare Zimbabwe

Phone: +263774 493522 E-mail: htaderera@gmail.com

Received: April 02, 2012 Accepted: June 05, 2012 DOI: 10.5296/jpag.v2i2.1614

\begin{abstract}
The years 2007 and 2008 are of special reckoned in the history of Zimbabwe as the economy plunged into a meltdown and professionalism suddenly became an irrelevant status. Institutions in the public sector struggled for relevance as they frantically sought to retain skilled and qualified medical personnel. The maternity service delivery system in local authorities could not escape from the crisis hence the study sought to explore the degree of staff attrition in the sector, major causes, effects and measures of reducing staff attrition. The study involved the collection and analysis of data from 12 council clinics providing maternity services for the period $2007-2008$. The authors argue that, the state of the economy has got a strong bearing on the level of staff attrition in organisations. Since medical staff are skilled professionals they can easily leave for greener "pastures" hence the need for Councils to improve working conditions.
\end{abstract}

Keywords: Staff attrition, Medical staff, Maternal death, Morbidity, Local government, Council clinics. 


\section{Background}

City health clinics were established through the Urban Councils Act administered by the Ministry of Local Government Rural and Urban Development. In Harare all the city health clinics are run by the city of Harare's Department of Health and virtually all suburbs in Harare have a city health clinic to cater for health demands in the communities they serve.

The impact of staff attrition on the health sector has been devastating. It is estimated that more than $80 \%$ of the doctors, nurses, pharmacists, radiologists and therapists who trained since 1980 have left the country (Chikanda, 2005:16). By 2003, the health sector had lost over 2,100 medical doctors and 1,950 State Certified Nurses, mostly to South Africa, Botswana, Namibia, UK and Australia. Consequently, service delivery has declined, mortality rates have increased and the public has lost confidence in these institutions (Chikanda, 2005:16).

\section{Causes of Staff Attrition}

There are many potential causes for turnover such as area economic conditions and labour market conditions that generally affect turnover rates and can be very difficult to manage. However, certain causes associated with turnover in any specific job or organization can be managed. These include such things as non-competitive compensation, high stress, working conditions, monotony, poor supervision, poor fit between the employee and the job, inadequate training, poor communications, and organization practices (Stoner, 2006:24).

Wrong positioning of employee in the organisation can lead to frustration due to failure to perform or lack of achievement in cases where an employee's job is too big or too small respectively (Kotler, 2002:76). Added to this is unrecognised effort, whereby an employee has done well but no notice is taken by management or supervisors. Another factor can be improper salary scales as exemplified by senior staff earning less than junior staff or the organisation paying non-competitive salaries. All these frustrations result in employees, who are forced to look elsewhere where their needs can be addressed.

Poor supervision and unsatisfied needs at the work place also contribute to high staff turnover (Stoner, 2006:24). Poor supervision, especially harsh supervision is retrogressive in that it makes employees feel inadequate therefore, they cannot perform well, at the same time they fear their superiors. Employees are constantly tense hence at some point they fail to bear the pressure and quit employment. Unsatisfied needs at the workplace can be related to the job itself or the benefits sought. If the work environment is not conducive in terms of safety, people will quit for fear of compromising their lives and health. Lack of adequate resources to use at work can also frustrate workers that are eager to perform, causing them to leave. In addition, if the benefits expected fall way below that which they were expecting, it becomes unworthy to continue working, resulting in resignations (Stoner, 2006:25). It is therefore apparent that there is a direct relationship between compensation and labour turnover. The bottom line being that if the compensation for an employee's services like monetary and non-monetary benefits are below the ones being offered by other firms in the global market, the employee is more likely to leave for greener pastures.

In some scenarios such as the Zimbabwean one, inflation played a significant part in worker 
frustration. Thus the value of money earned was quickly eroded by inflation, making it unwise to continue working. The emergence of the informal sector that was bringing in more rewards than the formal sector also caused staff to turn to this sector where they got quick returns (UNDP, 2008:32).

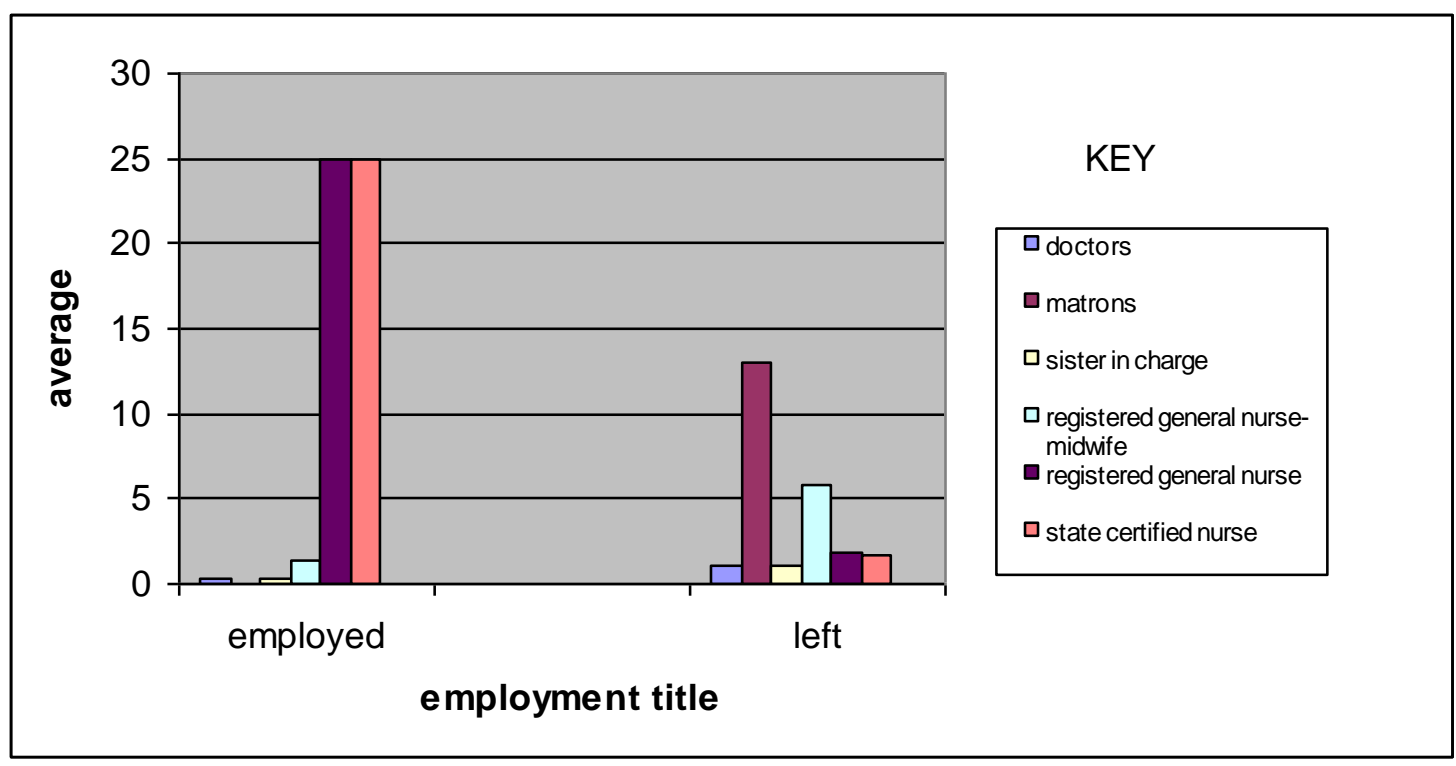

The above graph shows the changes in the staff complement of maternity clinics under analysis. The research revealed that while a certain number was employed to replace those leaving, less doctors and matrons were employed. A large number of lower level staff was employed compared to those who left on average. This might imply that low level staff is being employed to replace high level staff such as doctors and matrons.

\begin{tabular}{|l|l|l|l|}
\hline Factor & Major Effect \% & Minor Effect \% & No Effect \% \\
\hline Poor Remuneration & 87.5 & - & 12.5 \\
\hline Job Satisfaction & 87.5 & - & 12.5 \\
\hline Condition of Employment & 87.5 & - & 12.5 \\
\hline Unavailability of Resources & 87.5 & - & 12.5 \\
\hline Frustrations & 87.5 & - & 12.5 \\
\hline Deaths & 25 & 25 & 75 \\
\hline Dismissals & 12.5 & 25 & 87.5 \\
\hline Retirement & 25 & 12.5 & 62.5 \\
\hline
\end{tabular}

Table 1: Factors that caused high staff attrition 
The above table shows the responses to the likely causes of labour turnover that was put forward to the respondents. The findings of the research revealed that $87.5 \%$ of the respondents felt that poor remuneration, job satisfaction, poor conditions of service, unavailability of resources and frustration had a major effect on the labour turnover of City of Harare Clinics. Only $12.5 \%$ of the respondents felt that the factors had no effect on the staff turnover at maternity clinics. The research revealed that $37.5 \%$ of the respondents felt that retirement also contributed to labour turnover, $25 \%$ felt that death had an effect while $75 \%$ did not see the effect of death. Only $12.5 \%$ felt that dismissals had an effect on turnover whilst $87.5 \%$ felt that dismissals had no effect.

\section{Effects of High Medical Staff Attrition on Maternity Service Delivery}

High staff turnover has had a significant impact on the delivery of medical services such as maternity in particular. Such effects include mortality of mother and child i.e. maternal and prenatal mortality, as well as other complications on both mother and child (WHO, 2006:5). Mortality is incidence of death in a population. It is measured in various ways, often by the probability that a randomly selected individual in a population at some date and location would die in some period of time (WHO, 2006:6).

\subsection{Maternal Mortality}

Generally there is a distinction between a direct maternal death that is the result of a complication of the pregnancy, delivery, or their management, and an indirect maternal death that is a pregnancy-related death in a patient with a pre-existing or newly developed health problem (WHO, 2006:8). Other fatalities during but unrelated to pregnancy are termed accidental, incidental, or non-obstetrical maternal (WHO 2006:8). Maternal mortality is a sentinel event to assess the quality of a health care system. A health care system characterised by high staff turnover results in poor patient management leading to complications such as bacterial infection, toxaemia, post-partum haemorrhage, puerperal sepsis, and complications of abortions (WHO 2006:9). The net effect is however that of increased maternal mortality.

\subsection{Prenatal Mortality (PNM)}

The World Health Organization's definition of PNM is deaths occurring during late pregnancy (at 22 completed weeks gestation and over), during childbirth and up to seven completed days of life (WHO, 2006:9). This is one of the major mechanisms for assessing the quality of health care delivery. High staff turnover has been shown to contribute towards poor maternity service delivery thus prenatal mortality is usually high in such environments.

\subsection{Foetal mortality}

Neonatal/foetal mortality refers to stillbirths or foetal deaths. It encompasses any death of a foetus after 20 weeks of gestation or $500 \mathrm{gm}$ (Yeast et al, 2002:14). It is affected by the quality of in-hospital care for the neonate, good preconception health among women as well as adequate information and monitoring during pregnancy and delivery. This is only possible in environments that have adequate numbers of qualified medical personnel. Therefore if staff turnover is high, such programmes are difficult to implement and sustain. The result is increased foetal mortality among other maternity complications (Jejeebhoy et al, 2003:34). 


\begin{tabular}{|l|l|l|}
\hline Factor & $\begin{array}{l}\text { Associated } \\
\text { effect }(\%)\end{array}$ & $\begin{array}{l}\text { No effect } \\
(\%)\end{array}$ \\
\hline Longer Working Periods & 100 & - \\
\hline Patients Going Unattended & 37.5 & 62.5 \\
\hline Increased Referrals & 37.5 & 62.5 \\
\hline Lack of Continuity & 62.5 & 37.5 \\
\hline
\end{tabular}

Table 2: Associated Effects on Services Delivery

The table above shows the respondents' observations of the resultant effects of factors that affected service delivery in city health maternity clinics. All the respondents stated that staff attrition resulted in longer working hours, $37.5 \%$ stated that there was increase in patients going back home unattended and most patients being referred elsewhere. Lack of continuity in service delivery was cited by $62.5 \%$ of the respondents.

\section{Ways of Reducing Staff Attrition}

Staff attrition is becoming a serious problem in today's corporate environment as the employment culture is changing as well. It is now relatively common to change jobs every few years, rather than grow with one company throughout the employment life as was once commonplace. In addition, employees are increasingly demanding a balance between work and family life. This among other factors has prompted organisations to device mechanisms for reducing staff attrition. Some of the cited ways of reducing turnover include the following:

\subsection{Hire employees with the right "fit"}

According to Mushrush (2002:11) an organisation must hire people that are a good "fit" with the organisational culture; meaning that their values, principles, and goals must clearly match those of the company. Behavioural based interviewing and competency screening goes a long way in determining personality, work style and potential match and success within your company. At the same time, due consideration should be taken to hire people with the innate talent and ability to work in almost any position even if the "best" match is not available. Thus companies should hire the smartest people that can be found (Mushrush 2002:12).

\subsection{Hire older workers}

The hiring of older more mature employees is a pro-active way of reducing labour turnover at the selection level. Based on this argument, a limited number of workers than usual would frequently leave the organisation. Young employees tend to be "rolling stones that gather no moss" and as such employers should consider hiring older candidates who are seeking stability and not looking for the development opportunities that their younger counterparts may be in need of. In addition, older workers tend to be more motivated and highly engaged i.e. feel they can make a difference in critical areas of the business such as quality and 
customer service. They also believe they can influence key financial outcomes like cost, profitability and revenue growth (Feinsod and Davenport, 2006:20).

However, older employees are generally a financial burden to organisations through substantially higher medical claim costs, retirement benefits and employer-paid work-life benefits costs, specifically paid time off e.g. vacation, holidays and personal days.

\subsection{Describe the job correctly}

Employers should give a clear and accurate job description so candidates will know what is expected. Misconceptions regarding the job responsibilities and work environment are one of the major causes of employee turnover.

\subsection{Develop competitive compensation and benefit packages}

Under no circumstances should employees be ignored in the plans of the organisation. Investment in people through excellent remuneration packages, training and good working environments should not be perceived as necessary expenses (Nyambayo, 2008:13). Rodger et al., (2000:5), states that employees assess the availability of "greener pastures" and if these are available, employees leave the organisation. Though shareholders are important it is the employees that combine capital inputs, knowledge, processes and systems to create customer value that enables cash to flow into the organisation and should subsequently be adequately paid for their efforts. Thus, companies should understand and research market pay ranges and consider the value of benefits and employee perks. Offering such extras to the workforce may be the key to retaining them (Rodger et al., 2000:5). In Zimbabwe for instance, there have been attempts to arrest brain drain by bonding health professionals and working with donors, for example the Global Fund, to pay those health professionals that remained in the district hospitals and clinics in foreign currency allowances. This has seen a number of health professionals being retained but however the brain drain continues.

\subsection{Staff Empowerment}

Employees want to be challenged in the job they are performing to feel like they are growing both personally and professionally when challenged with attainable assignments. Employees can be challenged through empowering them. Empowerment is the management practice of sharing information, rewards, and power with employees so that they can take initiative and make decisions to solve problems and improve service and performance. It is based on the concept of giving employees the skills, resources, authority, opportunity, motivation, as well holding them responsible and accountable for outcomes of their actions (Business Dictionary, 2009:34).

In Wisconsin, USA, high turnover rates in the health care sector were reduced through implementing self-managed work teams (SMWTs). According to Yeatts and Seward (2000:19) an SMWT is a group of employees, typically ranging in size from 3 to 15 people, who are responsible for not only technical aspects of a job but management issues as well. Management responsibilities might include formulating a work plan, scheduling, and monitoring the team's performance. 
Research has found that under the right circumstances employees within SMWTs produce more at work than employees organised in a more hierarchical, traditional structure because they perform not only technical tasks but management duties as well. Further, case studies have shown that the decisions made by SMWTs can be extremely effective because those making the decisions (the team members) are the persons most knowledgeable about the work. Team members of the high-performing SMWT reported that the ability to participate in the decisions related to their work greatly increased their job satisfaction and desire to come to work (Yeatts and Seward 2000:29).

\subsection{Sound Leadership}

Nooteboom and Six (2001:16) identified four dimensions of trust: ability/competence, benevolence, dedication, and ethics. Ability is that group of skills, competences and characteristics that enable a party to have influence within some specific domain. Managers without demonstrated ability may not be able to influence and motivate employees leading to employees losing trust in those managers. Consequently, incompetent managers are often linked to increased employee turnover.

\subsection{Recognising employee success}

To retain and motivate employees, employers must not only provide monetary rewards but should also generously distribute non-monetary rewards. One of the simplest forms of non-monetary rewards is making employees feel that their work is not going unnoticed. Employees are more willing to stay with a company if they feel a sense of pride and success in their work. Thus when employees meet or surpass targets, management should show appreciation for the effort (Kotler, 2002:30).

\subsection{Providing an employee-friendly work environment}

"Trust influences communication, and communication influences trust. When leaders readily and consistently share information and involve employees in the running of business, good things result for both parties" (Zemke, 2000:11). By creating an open and informed atmosphere in the organisation through an "Open Door" policy amongst other measures employees are more relaxed at work and are likely to be more productive and satisfied (Zemke, 2000:21)

\subsection{Career Advancement Opportunities}

Employees seek to develop and improve themselves in the company. Management can assist through providing opportunities within the company for cross-training and career progression. Rodger et al (2000:32) indicate that if there is a lack of promotional chances within an organisation and an abundance of superior alternatives outside the organisation, staff turnover will be high as employees have an innate need to develop.

It is thus within the best interests of the organisation to promote suitable people and train promising employees. Research has clearly demonstrated that training is a key component to effectively reducing staff turnover (Yeast and Seward, 2000:14). The argument is that when training is aided by coaching and counselling, the culture of the organization of high staff turnover can be changed. 


\subsection{Conducting Exit Interviews and Snap Employee Surveys}

The bottom line is that it's extremely important to understand the impact of turnover in your organisation and determine the reasons why employees are leaving. The most effective way to do so is by conducting exit interviews with departing employees and regular snap employee surveys. This strategy alone will help the organisation make adjustments that will reduce future turnover (Stoner, 2006:58) The challenge however is that access to the leaving employees can sometimes be limited as some workers especially in Zimbabwe would go resign whilst on leave whilst some will just leave unceremoniously as the employment contract become meaningless.

\subsection{Reward and Recognition}

Lynn (2007:29), states that a monthly award with a plaque, recognition amongst peers, an early Friday finish for an employee who has excelled and movie tickets are a few suggestions. He goes on to suggest that organisations should never underestimate the power of a "Thank You". Recognition is closely coupled to the sense of involvement and it could be said that recognition creates a feeling of involvement. Recognition can take many forms. Redman (2008:18) supports this by stating that acknowledgement of a job well done and specific information of why the performance deserves your special attention is a good form of recognition. Recognition of a person who is working under difficulties such as pressure and stress, goes a long way to reducing the effects of the stress on the individual.

It is surprising the number of managers and supervisors who do not use recognition and praise as part of their leadership style. It is one of the most effective leadership tools and costs very little. Motivated contributors are proud employees. They feel they belong to something worthwhile. They feel they matter. Their performance reflects their self-image. Recognition has to be meaningful and specific. Letting employees know how much you appreciate their input makes them more receptive to what you are trying to do. On the other hand, meaningless praise serves only to confuse people about what behaviour is desirable and what isn't. Saying, "well done" to somebody is not specific enough and is unlikely to reinforce desirable behaviour (Redman 2008:15)

\begin{tabular}{|l|l|l|l|}
\hline Factor & Very effective \% & Slightly effective \% & Not effective \% \\
\hline Longer Working Hours & 25 & 62.5 & 12.5 \\
\hline Multi-Tasking & 25 & 37.5 & 37.5 \\
\hline $\begin{array}{l}\text { Training and } \\
\text { Development }\end{array}$ & 12.5 & 25 & 62.6 \\
\hline Recalling of Retirees & 12.5 & 50 & 37.5 \\
\hline Use Of Locums & 50 & 25 & 25 \\
\hline
\end{tabular}

Table 3: Measures Taken To Cope With Staff Shortage 


\section{MInstitute Machink $_{\text {Int }}$}

The table above shows the data on measures taken to cope with staff shortage. The research revealed that at least $62.5 \%$ of the respondents observed that longer working hours, multi-tasking, recalling of retirees and use of locums were effective strategies for coping with the challenges arising from high labour turnover. Training and development was not very effective as evidenced by $37.5 \%$ of the respondents agreeing with this strategy.

\begin{tabular}{|l|l|l|l|}
\hline Factor & Major effect $(\%)$ & Minor effect (\%) & No effect (\%) \\
\hline Adequate salaries & 100 & - & - \\
\hline Staff development & 100 & - & - \\
\hline Free treatment & 50 & 25 & 25 \\
\hline Adequate resources & 100 & - & - \\
\hline Job enrichment & 87.5 & - & 12.5 \\
\hline
\end{tabular}

Table 4: Possible Remedies

The table above highlights some of the research findings on the possible remedies to reduce staff turnover in maternity delivery systems. The data shows that 100 percent of the respondents felt that adequate salaries, staff development, and adequate resources would have a major effect as a remedy to staff turnover, while $87.5 \%$ felt that job enrichment could have the same effect. The research also reveals that $75 \%$ of the respondents believe that free treatment of their family members could work as a remedy to reduce staff turnover.

\section{Conclusions from the study}

The study focused on the analysis of medical staff attrition in local authorities. Specific attention was paid to the examination of the concept of labour turnover in relation to maternity service delivery in City of Harare clinics. The main thrust was to establish whether medical staff turnover affected maternity service delivery, the extent of the cause-effect relationship, as well as assessing current control measures and proposing further solutions.

Literature from various authorities revealed that labour turnover is a serious problem in the health sector with maternity service delivery not being an exception. Most writings in the field revealed that, where and when staff turnover is prevalent, the quality of maternity service delivery will be highly compromised as the few medical staff available struggle to cope with the additional workload.

Major effects of medical staff turnover have been recorded over time in extreme cases to be in the form of maternity and foetal death. The majority of literature consent to the fact that a significant number of factors lead to high labour turnover in the medical fraternity. There are both push and pull factors with regard to the nature of the organisation's micro and macro environment.

Theories put forward with respect to the concept of labour turnover generally note the lack of 
motivation as the major contributing factor to higher labour turnover although they differ in terms of the means of motivation. Empirical findings from the field research also support motivation as having a major effect on turnover particularly in City of Harare clinics where the majority of medical staff is alleged to be striving for physiological needs.

The research has also established that during the period under inquiry (2007-2008) the quality of maternity service delivery has been on the decline although the majority of patients' responses were not totally negative. The responses obtained from medical personnel, however, showed that during the period under study the majority of medical staff left in pursuit of greener pastures as the country was experiencing negative growth. As a result, the additional workload on the remaining staff led to compromised service delivery.

Questionnaires delivered to respondents in city clinics revealed that the number of booked patients dropped by almost 50\% between the years 2007 and 2008. This development was largely attributed to the loss of confidence in the city clinics by the majority of patients. It is worthwhile to note that even though there is a link between labour turnover and maternity service delivery, labour turnover is not the sole factor that led to compromised maternity service delivery. For instance, lack of adequate and improved technology was cited by many respondents as a significant cause of compromised service delivery.

\section{Recommendations}

In light of the previously mentioned findings it is critical that some mitigating measures be undertaken to lessen the impact on patients and reduce avoidable loss of life, whilst simultaneously improving performance. This would enable the city clinics to realize more positive and sustainable deliverables.

Since the majority of respondents highlighted that competitive salaries have a major impact on reducing labour turnover it is essential for city clinics to adjust remuneration for medical staff in line with packages offered in the private, regional and international medical sectors. This will make the city clinics an attractive place to work.

Another important requirement is the provision of adequate resources to be utilised by the medical staff. The majority of respondents indicated that working without adequate resources can be frustrating to the employee leading to the inevitable consequence of resignation. It therefore follows that the requisite equipment, technology and support need to be made available in order to retain staff. This can be achieved by engaging the donor community for support as a complement to government efforts. Smart partnerships may also be entered into by city clinics and players from the private sector.

One of the most important factors often overlooked by organizations is a holistic approach towards capacity building. This entails building capacity in its entirety from human resources, technical, administrative, finance to institutional capacity building. For instance apart from training and development of workers there is need to restructure, revamp and right-size and realign city clinics to make them more efficient and effective in service delivery.

There is also need for staff development opportunities to be made available to medical staff, coupled by job enrichment opportunities. This is meant to give medical staff a sense of 


\section{I Macrothink}

Journal of Public Administration and Governance ISSN 2161-7104 2012, Vol. 2, No. 2

belonging, recognition and motivation. In addition, benefits like free treatment of family members would also play a motivational role to the medical staff.

Staff turnover is indeed a problem in the City of Harare health delivery system. Its effects on maternity service delivery negatively affect the population at large as they can result in the death of mothers and children. However, this can be stemmed by the adoption of applicable staff retention strategies by the City Health department, so that staff members are motivated enough to stay in service and perform as best as they can.

\section{References}

Bergh, Z. C. and Theron, A. L. (1999). Psychology in the Work Context, Oxford University Press, Oxford.

Black, A. and Black, C. (2006). Business, the Ultimate Resource, Harvard Business Review.

Bloch, A. (2005). "The Development Potential of Zimbabweans in the Diaspora", IOM, Migration Research Series No. 17.

Central Statistics Office, (2006). "Zimbabwe Demographic and Health Survey 2005-2006" Preliminary Report, Harare.

Chikanda, A. (2005). "Medical Leave: The Exodus of Health Professionals from Zimbabwe", Idasa, Southern African Migration Project, Migration Policy Series No. 34.

Feinsod, R. and Davenport, T. O. (2006). "The Aging Workforce: Challenge or Opportunity?", World at Work Journal, Third Quarter, Vol. 15, No. 3, 14-23

Fitch, D. (2005). "Does uHu accurately measure workload?" Management Focus 20 (3): 1-2.

Holbeche, L. (2005). The High Performance Organization, Elsevier Butterworth-Heinemann

Jejeebhoy, S. J, (2003). Reproductive Tract Infections and Other Gynaecological Disorders: A Multidisciplinary Research Approach, University Press, Cambridge.

Kotler, P. (2002). Marketing Management, Prentice-Hall, New York.

Lacey, L. and Shaver, K. (2001). Findings from the 2001 Survey of Staff Nurses in North Carolina. Online Available: www.nursenc.org/research/retain-staff.pdf. (September 30 2009)

Lowe, B. and Bolton, B. (2002). " $21^{\text {st }}$ Century EMS Retention Strategies". Emergency Medical Services, Vol. 31(11): 75-77.

Makina, D. (2007). Survey of the Profile of Migrant Zimbabweans in South Africa. Online Available:http://www.idasa.org.za/gbOutputFiles.asp?WriteContent=Y\&RID=2220

(September 26 2009)

Manion, J. and Bartholomew, K. (2004). "Community in the workplace: A proven retention strategy”, Journal of Nursing Administration, Vol. 34(1): 46-53.

Martin, C. (2004). "Staying power”. Nursing Management, Vol. 35(3): 20-27. 


\section{Macrothink}

Journal of Public Administration and Governance ISSN 2161-7104 2012, Vol. 2, No. 2

Ministry of Health - New Zealand, (2007), "Maternity Services: Notice Pursuant To Section 88 Of The New Zealand Public Health And Disability Act", New Zealand Gazette, No. 41

Mushrush, W. (2002). “Creating Quality” Newsletter, May, Vol. 11, No. 5

Nooteboom, B. and Six, F. (2001). The Trust Process in Organizations: Empirical Studies of the Determinants and the Process of Trust Development, Edward Elgar Publishing Limited, Cheltenham.

Rambur, B. et al., (2003). "A Statewide Analysis of RNs' Intention to Leave Their Position”, Nursing Outlook, Vol. 51(4):182-187.

Rodger, W. et al., (2000). "A Meta-Analysis of Antecedents and Correlates of Employee Turnover: Update, Moderator Tests, and Research Implications for the Next Millennium”, Journal of Management, Vol. 26, No. 463

Sasichay-Akkadechanunt T, Scalzi C, Jawad A. (2003). "The Relationship between Nurse Staffing and Patient Outcomes”. Journal of Nursing Administration, Vol. 33(9): 478-485.

Smit, P. J. and Cronje, G. J. (1999). Management Principles, $2^{\text {nd }}$ Ed, Juta \& Co. Ltd, Boston.

Stoner, J. (2006). Management $6^{\text {th }}$ Ed, Prentice-Hall, New York.

Thomson, R. (2002). Managing People, $3^{\text {rd }}$ Ed, Elsevier Butterworth-Heinemann

United Nations Development Program - Zimbabwe (2008). “A Comprehensive Economic Recovery Document”: A Discussion Document, Harare.

Upenieks, V. (2003). "What's the attraction to magnet hospitals?" Nursing Management Journal, Vol. 34(2): 43-44

Williams, D.M. (2005). “JEMS Salary \& Workplace Survey”. JEMS, Vol. 30(10): 36-55.

World Health Organization (2006), Neonatal and Prenatal Mortality: Country, Regional and Global Estimates, WHO Press, Geneva.

World Health Organization, (2006). Country Health System Fact Sheet 2006 Zimbabwe, Harare.

Yeast, J.D. et al. (1998). "Changing Patterns in Regionalization of Perinatal Care and the Impact on Neonatal Mortality", American Journal of Obstetrics and Gynaecology, Vol. 178:131-5.

Yeatts, D. E. and Seward, R. R. (2000). "Reducing Turnover and Improving Health Care in Nursing Homes: The Potential Effects of Self-Managed Work Teams", The Gerontologist_Vol. 40, No. 3, $358-363$

Zemke, R. (2000). “Can You Manage Trust?” Training, Vol. 37. 76-83 